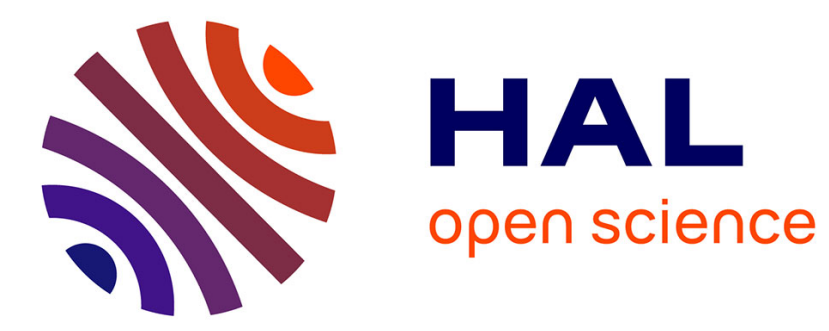

\title{
Luteinizing hormone in testicular descent
}

Jorma Toppari, Marko Kaleva, Helena E. Virtanen, Katharina M. Main, Niels

E. Skakkebæk

\section{To cite this version:}

Jorma Toppari, Marko Kaleva, Helena E. Virtanen, Katharina M. Main, Niels E. Skakkebæk. Luteinizing hormone in testicular descent. Molecular and Cellular Endocrinology, 2007, 269 (1-2), pp.34. 10.1016/j.mce.2006.10.021 . hal-00531902

\section{HAL Id: hal-00531902 https://hal.science/hal-00531902}

Submitted on 4 Nov 2010

HAL is a multi-disciplinary open access archive for the deposit and dissemination of scientific research documents, whether they are published or not. The documents may come from teaching and research institutions in France or abroad, or from public or private research centers.
L'archive ouverte pluridisciplinaire HAL, est destinée au dépôt et à la diffusion de documents scientifiques de niveau recherche, publiés ou non, émanant des établissements d'enseignement et de recherche français ou étrangers, des laboratoires publics ou privés. 


\section{Accepted Manuscript}

Title: Luteinizing hormone in testicular descent

Authors: Jorma Toppari, Marko Kaleva, Helena E. Virtanen, Katharina M. Main, Niels E. Skakkebæk

PII: $\quad$ S0303-7207(07)00044-5

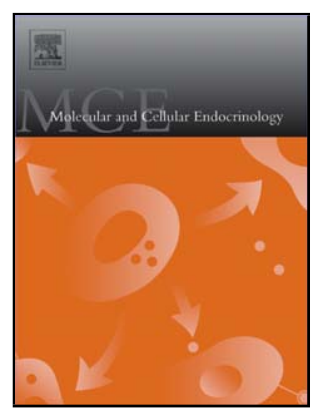

DOI: doi:10.1016/j.mce.2006.10.021

Reference: MCE 6610

To appear in: Molecular and Cellular Endocrinology

Received date: $1-8-2006$

Revised date:

3-10-2006

Accepted date:

3-10-2006

Please cite this article as: Toppari, J., Kaleva, M., Virtanen, H.E., Main, K.M., Skakkebæk, N.E., Luteinizing hormone in testicular descent, Molecular and Cellular Endocrinology (2007), doi:10.1016/j.mce.2006.10.021

This is a PDF file of an unedited manuscript that has been accepted for publication. As a service to our customers we are providing this early version of the manuscript. The manuscript will undergo copyediting, typesetting, and review of the resulting proof before it is published in its final form. Please note that during the production process errors may be discovered which could affect the content, and all legal disclaimers that apply to the journal pertain. 


\section{Luteinizing hormone in testicular descent}

Jorma Toppari ${ }^{\mathrm{a}}$, Marko Kaleva ${ }^{\mathrm{a}}$, Helena E. Virtanen ${ }^{\mathrm{a}}$, Katharina M. Main ${ }^{\mathrm{b}}$, Niels E. Skakkebæk ${ }^{\mathrm{b}}$

${ }^{\mathrm{a}}$ Departments of Physiology and Paediatrics, University of Turku, Kiinamyllynkatu 10, FI-20520 Turku, Finland,

bUniversity Department of Growth and Reproduction, GR 5064, Rigshospitalet, DK-2100

Copenhagen, Denmark

Corresponding author:

Jorma Toppari

University of Turku

Kiinamyllynkatu 10

20520 Turku

Finland

Tel: + 35823337579

Fax: +35822502610

E-mail: jorma.toppari@utu.fi 


\section{Summary}

A proper hypothalamus-pituitary-testis axis with normal androgen synthesis and action is a prerequisite for normal testicular descent. Various defects in this axis may result in cryptorchidism but endocrine abnormalities are rarely detected. Androgens regulate testicular descent but androgen action alone is not sufficient for normal testicular descent. The regulation of androgen production is influenced both by placental human chorionic gonadotropin (hCG) and pituitary luteinizing hormone (LH). There is evidence that the longer pregnancy continues, the more important role pituitary LH may have. INSL3 (insulin-like hormone-3) is suggested to be the main regulator of gubernacular development and therefore an apparent regulator of testicular descent. INSL3 production is also related to LH, and reduced INSL3 action is a possible cause for cryptorchidism. Cryptorchid boys have normal testosterone levels with slightly but significantly elevated LH levels as compared to healthy boys. This high gonadotropin drive may compensate for mild Leydig cell dysfunction in cryptorchidism.

Keywords: Luteinizing hormone; Testosterone; INSL3; Testicular descent; Cryptorchidism 
Introduction

Development of normal male genitalia is a complex series of events including a unique process of testicular descent from intra-abdominal location into the bottom of the scrotum. Usually testes reach the scrotum during the last few weeks of pregnancy or soon after birth (Ghirri et al., 2002). However, disorders in this process are common and cryptorchidism (undescended testis) is the most common congenital abnormality of newborn boys affecting 2-9 \% of boys at birth (Boisen et al., 2004; Toppari and Kaleva, 1999). Seasonal variation and great regional differences in the incidence of cryptorchidism point to environmental effects behind the disorder (Kaleva et al., 2005a; Boisen et al., 2004).

There is evidence that testicular descent occurs in two phases, of which only the latter (inguinoscrotal) phase is androgen dependent (Fig. 1). This is suggested by the observation that hypogonadotropic hypogonadism and androgen insensitivity often result in cryptorchidism but usually only the inguinoscrotal descent has failed to occur and the testes are located in the inguinal region (Boehmer et al., 2001). The critical role of androgens in testicular descent is suggested also by the fact that a high percentage of cryptorchidism resolves spontaneously (Boisen et al., 2004) during the period of high serum gonadotropin and steroid hormone levels at the age of 1 - 3 months (Andersson et al., 1998). 


\section{human chorionic gonadotropin and luteinizing hormone}

Gonadotropin-releasing hormone $(\mathrm{GnRH})$ regulates the production of pituitary gonadotropins, FSH and $\mathrm{LH}$, which are the main regulators of postnatal testicular action. LH stimulates Leydig cells to produce testosterone, while FSH regulates Sertoli cell function. In rodents, testosterone production starts independently from endogenous circulating gonadotropins and Leydig cells become dependent on gonadotropins shortly after birth (El-Gehani et al., 1998; O'Shaughnessy et al., 1998). Unlike in rodents, human fetal testis binds hCG (human chorionic gonadotropin) and physiologic levels of hCG stimulate testosterone production already at early pregnancy, at least from 14 weeks of gestation (Huhtaniemi et al., 1977). Because hypogonadotropic hypogonadism often results in cryptorchidism regardless of normal placental hCG production, endogenous fetal pituitary LH (luteinizing hormone) seems to be a more important regulator of fetal testosterone synthesis in late pregnancy (Quinton et al., 2001). The fact that hypogonadotropic hypogonadism is one of the reasons for cryptorchidism also contributes to the confusion in studies in which varying results have been reported about the endocrine status of cryptorchid boys, i.e. hypogonadotropic and hypergonadotropic patients have been mixed together. Hypogonadotropic hypogonadism is rare, whereas cryptorchidism is very common, and most cases have slightly elevated gonadotropin levels (Suomi et al., 2006).

Variant-LH (V-LH) is a common genetic variant of LH with two point mutations in its $\beta$ subunit gene (Pettersson et al., 1992). V-LH represents a biologically less active form of LH (Lamminen and Huhtaniemi, 2001) and it is associated with slower progression of 
puberty in healthy boys (Raivio et al., 1996). Despite reduced biological activity of V$\mathrm{LH}$, the prevalence of V-LH was not higher among cryptorchid boys $(26.9 \%)$ as compared to healthy controls $(26.1 \%)$ but the proportion of boys with homozygous $\mathrm{V}$ LH was two times higher in cryptorchid group (6.5\% vs. $2.8 \%$ ) (Kaleva et al., 2005b). Differently from the control boys, the prevalence of V-LH among cryptorchid boys increased steadily with gestational age (GA <37 weeks: 6.7 \%; GA 37 - 39 weeks: 20.9 $\%$; and GA 40-42 weeks $42.9 \%$ ). These results support the theory that the longer pregnancy continues, the more important role LH may have for testicular descent. The weaker V-LH is not as effective as wild type LH to stimulate normal testicular descent in late pregnancy. The increasing relative importance of pituitary LH, in comparison to $\mathrm{hCG}$, is also supported by the finding that testosterone dependent penile growth is not affected in hypothalamic / pituitary dysfunction before the second half of gestation (Feldman and Smith, 1975), leading to micropenis but not hypospadias.

Decreased serum testosterone and LH levels have been reported in some studies on cryptorchidism (Bollerslev et al., 1986; Job et al., 1988) but endocrine abnormalities are not always detected. However, cryptorchidism is not one specific entity, but various forms of cryptorchidism (congenital with/without spontaneous descent, mild vs. severe, acquired cryptorchidism) might show distinct hormonal patterns which differ from each other (Suomi et al., 2006). In our study, a clear pattern of hormonal changes was seen in Finnish cryptorchid boys. Their inhibin B values were significantly lower and FSH values were significantly higher as compared to healthy controls. In addition, the effect of cryptorchidism on FSH and inhibin B levels correlated with the severity of the ailment. 
Significantly lower testosterone levels were seen in severely and persistently cryptorchid boys whereas in milder forms of cryptorchidism normal testosterone levels were detected. However, cryptorchid boys had significantly increased LH as compared to controls. This high gonadotropin drive suggests a mild Leydig cell dysfunction in cryptorchidism. Moreover, we found reduced androgen bioactivity at three months of age in severe cryptorchidism (Raivio et al., 2003).

\section{Insulin-like hormone-3}

It is known, that the androgen receptor is expressed in the male reproductive tract and adequate androgen action is obligatory, but not sufficient alone, for normal testicular descent. High androgen levels in congenital adrenal hyperplasia do not induce ovarian descent. In male rat fetus, androgens cause the regression of the cranial suspensory ligament and regulate the gubernacular outgrowth together with INSL-3 (Emmen et al., 1998; Emmen et al., 2000). INSL-3 (insulin-like hormone-3, also known as relaxin-like factor (RLF)) is an apparent regulator of testicular descent in rodents. Male mice mutant for INSL-3 were cryptorchid (Zimmermann et al., 1999) whereas in female mice the overexpression of INSL-3 caused ovarian descent (Adham et al., 2002). LGR-8 (also known as GREAT) is a receptor for INSL-3 (Kumagai et al., 2002) and in mouse its mutation caused cryptorchidim similar to deletions of the INSL-3 gene (Overbeek et al., 2001). Studies performed in men suggest that INSL3 and its receptor LGR8 are also involved in testicular descent in human embryogenesis (Ferlin et al., 2003; Gorlov et al., 2002; Tomboc et al., 2000). In human, several polymorphisms in INSL-3 / LGR-8 genes 
have been identified but deleterious mutations are only occasionally associated with cryptorchidism (Koskimies et al., 2000; Roh et al., 2003; Adham and Agoulnik, 2004) .

INSL3 circulates in adult men (Bay et al., 2005; Ferlin and Foresta, 2005) which suggests that INSL3 has endocrine functions also in adulthood. INSL3 is a sensitive marker of Leydig cell function (Foresta et al., 2004) but its production is regulated by LH differently from that of testosterone (Bay et al., 2005). In rodents, INSL3 prevents apoptosis of germ cells during spermatogenesis (Kawamura et al., 2004). In our material cryptorchidism was associated with reduced INSL3 levels at the age of three months (unpublished data). A high gonadotropin drive together with reduced INSL3 levels suggests an impaired Leydig cell function and supports the theory of a mild primary testicular disorder at least in severe cryptorchidism.

\section{Acknowledgements}

This work was funded by Turku University Central Hospital, the Academy of Finland, Sigrid Jusélius Foundation, the Nordic Academy for Advanced Study, The Danish Medical Research Council, Svend Andersens Fond, the University of Copenhagen, the Novo Nordisk Foundation and the European Commission (contracts BMH4-CT96-0314, QLK4-CT1999-01422, QLK4-2001-00269, and QLK4-2002-0063). 
References

Adham IM, Agoulnik AI. (2004). Insulin-like 3 signalling in testicular descent. Int $J$ Androl 27(5):257-265.

Adham IM, Steding G, Thamm T, Bullesbach EE, Schwabe C, Paprotta I, et al. (2002). The overexpression of the insl3 in female mice causes descent of the ovaries. Mol Endocrinol 16(2):244-252.

Andersson AM, Toppari J, Haavisto AM, Petersen JH, Simell T, Simell O, et al. (1998). Longitudinal reproductive hormone profiles in infants: peak of inhibin B levels in infant boys exceeds levels in adult men. $J$ Clin Endocrinol Metab 83(2):675-681.

Bay K, Hartung S, Ivell R, Schumacher M, Jurgensen D, Jorgensen N, Holm M, Skakkebaek NE, Andersson AM. (2005). Insulin-like factor 3 serum levels in 135 normal men and 85 men with testicular disorders: relationship to the luteinizing hormonetestosterone axis. J Clin Endocrinol Metab 90(6):3410-3418.

Boehmer AL, Brinkmann O, Bruggenwirth H, van Assendelft C, Otten BJ, VerleunMooijman MC, et al. (2001). Genotype versus phenotype in families with androgen insensitivity syndrome. J Clin Endocrinol Metab 86(9):4151-4160.

Boisen KA, Kaleva M, Main KM, Virtanen HE, Haavisto AM, Schmidt IM, et al. (2004). Difference in prevalence of congenital cryptorchidism in infants between two Nordic countries. Lancet 363(9417):1264-1269. 
Bollerslev J, Rohl H, Krag Sorensen E, Bennet P. (1986). Gonadotropin and androgen levels in patients operated upon for cryptorchidism. Dan Med Bull 33(6):336-338.

El-Gehani F, Zhang FP, Pakarinen P, Rannikko A, Huhtaniemi I. (1998). Gonadotropinindependent regulation of steroidogenesis in the fetal rat testis. Biol Reprod 58(1):116123.

Emmen JM, McLuskey A, Grootegoed JA, Brinkmann AO. (1998). Androgen action during male sex differentiation includes suppression of cranial suspensory ligament development. Hum Reprod 13(5):1272-1280.

Emmen JM, McLuskey A, Adham IM, Engel W, Grootegoed JA, Brinkmann AO. (2000). Hormonal control of gubernaculum development during testis descent: gubernaculum outgrowth in vitro requires both insulin-like factor and androgen. Endocrinology 141(12):4720-4727.

Feldman KW, Smith DW. (1975). Fetal phallic growth and penile standards for newborn male infants. J Pediatr 86(3):395-398.

Ferlin A, Foresta C. (2005). Insulin-like factor 3: a novel circulating hormone of testicular origin in humans. Ann N Y Acad Sci 1041:497-505.

Ferlin A, Simonato M, Bartoloni L, Rizzo G, Bettella A, Dottorini T, et al. (2003). The INSL3-LGR8/GREAT ligand-receptor pair in human cryptorchidism. J Clin Endocrinol Metab 88(9):4273-4279. 
Foresta C, Bettella A, Vinanzi C, Dabrilli P, Meriggiola MC, Garolla A, et al. (2004). A novel circulating hormone of testis origin in humans. J Clin Endocrinol Metab 89(12):5952-5958.

Ghirri P, Ciulli C, Vuerich M, Cuttano A, Faraoni M, Guerrini L, et al. (2002). Incidence at birth and natural history of cryptorchidism: a study of 10,730 consecutive male infants. J Endocrinol Invest 25(8):709-715.

Gorlov IP, Kamat A, Bogatcheva NV, Jones E, Lamb DJ, Truong A, et al. (2002). Mutations of the GREAT gene cause cryptorchidism. Hum Mol Genet 11(19):2309-2318.

Huhtaniemi IT, Korenbrot CC, Jaffe RB. (1977). HCG binding and stimulation of testosterone biosynthesis in the human fetal testis. J Clin Endocrinol Metab 44(5):963967.

Job JC, Toublanc JE, Chaussain JL, Gendrel D, Garnier P, Roger M. (1988). Endocrine and immunological findings in cryptorchid infants. Horm Res 30(4-5):167-172.

Kaleva M, Virtanen HE, Haavisto AM, Main KM, Reunanen M, Skakkebaek NE, Toppari J. (2005a). Circannual rhythm in the incidence of cryptorchidism in Finland. Int J Androl 28(1):53-7. 
Kaleva M, Virtanen H, Haavisto AM, Main K, Skakkebaek NE, Huhtaniemi I, et al. (2005b). Does variant luteinizing hormone (V-LH) predispose to improper testicular position in late pregnancy? Pediatr Res 58(3):447-450.

Kawamura K, Kumagai J, Sudo S, Chun SY, Pisarska M, Morita H, Toppari J, Fu P, Wade JD, Bathgate RA, Hsueh AJ. (2004). Paracrine regulation of mammalian oocyte maturation and male germ cell survival. Proc Natl Acad Sci U S A 101(19):7323-7328.

Koskimies P, Virtanen H, Lindstrom M, Kaleva M, Poutanen M, Huhtaniemi I, Toppari J. (2000). A common polymorphism in the human relaxin-like factor (RLF) gene: no relationship with cryptorchidism. Pediatr Res 47(4 Pt 1):538-541.

Kumagai J, Hsu SY, Matsumi H, Roh JS, Fu P, Wade JD, et al. (2002). INSL3/Leydig insulin-like peptide activates the LGR8 receptor important in testis descent. J Biol Chem 277(35):31283-31286.

Lamminen T, Huhtaniemi I. (2001). A common genetic variant of luteinizing hormone; relation to normal and aberrant pituitary-gonadal function. Eur J Pharmacol 414(1):1-7.

O'Shaughnessy PJ, Baker P, Sohnius U, Haavisto AM, Charlton HM, Huhtaniemi I. (1998). Fetal development of Leydig cell activity in the mouse is independent of pituitary gonadotroph function. Endocrinology 139(3):1141-1146. 
Overbeek PA, Gorlov IP, Sutherland RW, Houston JB, Harrison WR, Boettger-Tong HL, et al. (2001). A transgenic insertion causing cryptorchidism in mice. Genesis 30(1):2635.

Pettersson K, Ding YQ, Huhtaniemi I. (1992). An immunologically anomalous luteinizing hormone variant in a healthy woman. J Clin Endocrinol Metab 74(1):164-171.

Quinton R, Duke VM, Robertson A, Kirk JM, Matfin G, de Zoysa PA, et al. (2001). Idiopathic gonadotrophin deficiency: genetic questions addressed through phenotypic characterization. Clin Endocrinol (Oxf) 55(2):163-174.

Raivio T, Toppari J, Kaleva M, Virtanen H, Haavisto AM, Dunkel L, et al. (2003). Serum androgen bioactivity in cryptorchid and noncryptorchid boys during the postnatal reproductive hormone surge. J Clin Endocrinol Metab 88(6):2597-2599.

Raivio T, Huhtaniemi I, Anttila R, Siimes MA, Hagenas L, Nilsson C, et al. (1996). The role of luteinizing hormone-beta gene polymorphism in the onset and progression of puberty in healthy boys. J Clin Endocrinol Metab 81(9):3278-3282.

Roh J, Virtanen H, Kumagai J, Sudo S, Kaleva M, Toppari J, Hsueh AJ. (2003). Lack of LGR8 gene mutation in Finnish patients with a family history of cryptorchidism. Reprod Biomed Online 7(4):400-406.

Suomi AM, Main KM, Kaleva M, Schmidt IM, Chellakooty M, Virtanen HE, et al. (2006). Hormonal changes in 3-month-old cryptorchid boys. J Clin Endocrinol Metab 
Tomboc M, Lee PA, Mitwally MF, Schneck FX, Bellinger M, Witchel SF. (2000).

Insulin-like 3/relaxin-like factor gene mutations are associated with cryptorchidism. $J$ Clin Endocrinol Metab 85(11):4013-4018.

Toppari J, Kaleva M. (1999). Maldescendus testis. Horm Res 51(6):261-269.

Zimmermann S, Steding G, Emmen JM, Brinkmann AO, Nayernia K, Holstein AF, et al. (1999). Targeted disruption of the Insl3 gene causes bilateral cryptorchidism. Mol Endocrinol 13(5):681-691. 
Figure legends

Figure1. Schematic presentation of testicular descent. The first part is called as transabdominal phase that is regulated by INSL3 through gubernacular development. The second part is inguinoscrotal phase that is mediated by androgens. Cranial mesonephric ligament is also known as cranial suspensory ligament or cranial gonadal ligament. 


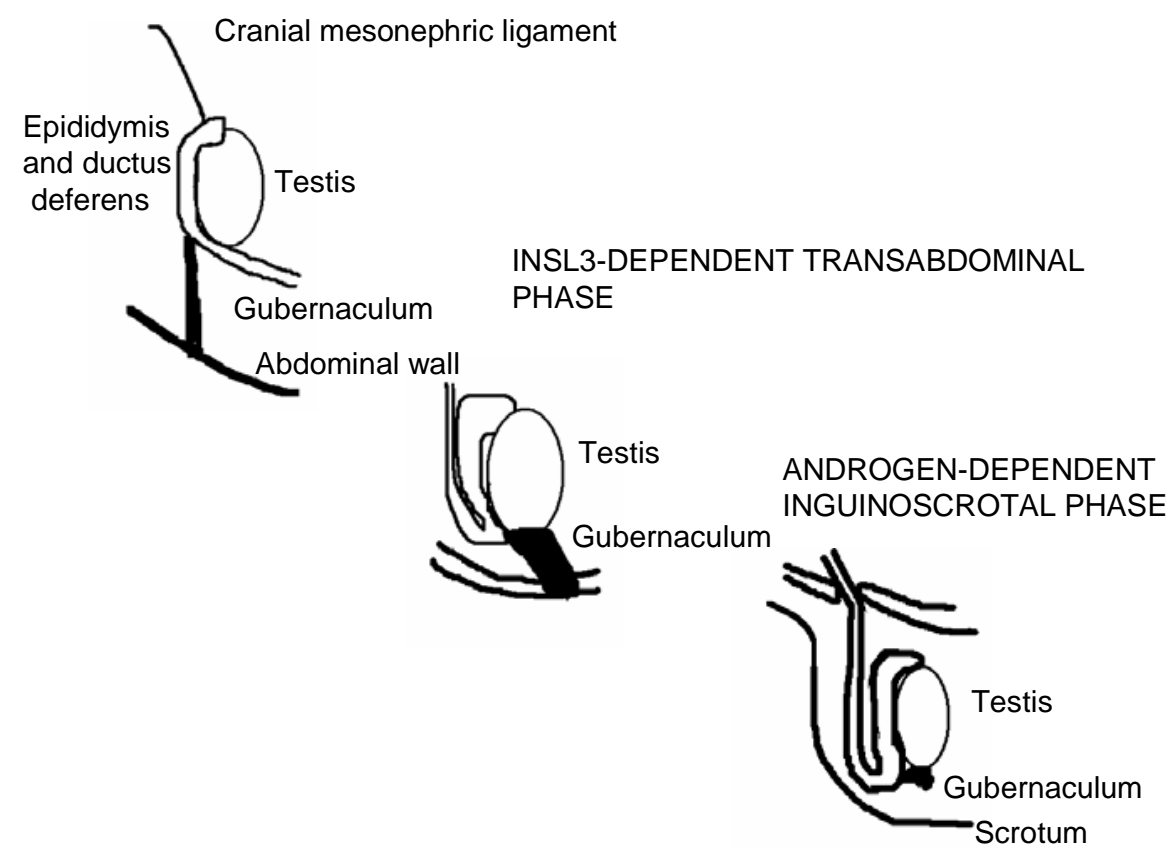

Fig. 1. 